\title{
UJI AKTIVITAS ANTIBAKTERI EKSTRAK $n$-HEKSAN, ETIL ASETAT DAN ETANOL KULIT BATANG KAYU EBONI (Diospyros celebica Bakh.) MENGGUNAKAN METODE DIFUSI
}

\section{[The Antibacterial Activity Test on $n$-Hexane, Ethyl Acetate, and Ethanol Extracts of Ebony Bark (Diospyros Celebica Bakh.) Using Diffusion Method]}

\author{
Ni Luh Sumitriasih ${ }^{1^{\star}}$, Ahmad Ridhay ${ }^{1}$, Indriani ${ }^{1}$ \\ 1) Jurusan Kimia, Fakultas MIPA, Universitas Tadulako, Palu \\ Jl. Soekarno Hatta Km.9, Kampus Bumi Tadulako Tondo Palu, Telp. 0451- 422611
}

*)Coresponding author: niluhsumitriasih@gmail.com (hp.082136622915)

Diterima 15 Desember 2018, Disetujui 9 Oktober 2019

\begin{abstract}
A study was conducted on the antibacterial activity test on $n$-hexane, ethyl acetate, and ethanol extracts of ebony bark (Diospyros celebica Bakh.) using a diffusion method. The purpose of this research is to know the antibacterial activity of ebony bark against Staphylococcus aureus and Eshericia coli bacteria using $n$-hexane, ethyl acetate dan ethanol. The method of extraction used in this research was maceration method with three polarity levels of solvent. The antibacterial activity test was performed by diffusion-well test. The results showed that ethyl acetate extract gave the highest inhibition of $26.14 \mathrm{~mm}$ in gram-positive bacteria (Staphylococcus aureus) and ethanol extract of $25.97 \mathrm{~mm}$ in gram-negative bacteria (Escherichia coli).
\end{abstract}

Keywords: Ebony (Diospyros celebica. Bakh), tree bark, inhibitory, antibacterial

\begin{abstract}
ABSTRAK
Telah dilakukan penelitian uji aktivitas antibakteri terhadap ekstrak n-heksan, etil asetat dan etanol kulit batang kayu eboni (Diospyros celebica Bakh.) menggunakan metode difusi. Tujuan penelitian ini adalah mengetahui aktivitas antibakteri dari kulit batang kayu eboni terhadap bakteri Staphylococcus aureus dan Eschericia coli menggukan pelarut $n$-heksan, etil asetat dan etanol. Metode ekstraksi yang digunakan dalam penelitian yaitu metode maserasi dengan tiga tingkat kepolaran pelarut. Pengujian aktivitas antibakteri dilakukan dengan uji metode sumur difusi. Hasil penelitian menunjukan bahwa ekstrak etil asetat memberikan daya hambat tertinggi $26,14 \mathrm{~mm}$ pada bakteri gram positif (Staphylococcus aureus) dan ekstrak etanol 25, $97 \mathrm{~mm}$ pada bakteri gram negatif (Escherichia coli).
\end{abstract}

Kata kunci : Eboni (Diospyros celebica Bakh.), kulit kayu, daya hambat, antibakteri 


\section{LATAR BELAKANG}

Indonesia merupakan negara dengan kekayaan hayati terbesar kedua setelah Brazil. Tumbuhan yang ditemukan di hutan Indonesia diperkirakan 30.000 jenis di antaranya adalah tumbuhan endemik. Salah satu tumbuhan endemik adalah kayu Eboni (Diospyros celebica Bakh.) yang hanya terdapat di wilayah hutan Sulawesi (Isnindar et al., 2011).

Eboni (Diospyros celebica Bakh.) adalah nama pohon penghasil kayu yang mempunyai nilai komersial tinggi, yang termasuk dalam marga Diospyros L. dari suku Ebenaceae. Kayu eboni banyak digunakan untuk pembuatan mebel, patung, ukir-ukiran, alat-alat untuk dekorasi dan juga untuk konstruksi bangunan seperti tiang rumah dan jembatan (Allo, 2011).

Di beberapa negara tumbuhan genus Diospyros digunakan sebagai obat tradisional seperti obat batuk, cegukan dan antibiotik (Mallavadhani, 1998). Sumber senyawa alam sebagian besar berasal dari tumbuhan, baik berupa akar, kulit batang, daun, bunga, atau bijinya. Salah satu bioaktivitas dari senyawa alam yang banyak di teliti adalah sebagai antibakteri, yang memiliki kemampuan untuk melawan bakteri (Dzen et al., 2003).

Menurut Borges et al. (2007) melakukan pengujian antimikroba fraksi heksan kulit batang Diospyros anisandra terhadap Mycobakterium tuberculosis yang resisten terhadap antibiotik memiliki aktivitas yang sangat kuat dengan nilai sebesar 6,25 ug/ml.

Beberapa peneliti melaporkan bahwa tumbuhan sejenis dengan kayu eboni ini mengandung senyawa golongan metabolit sekunder, daun kesemek (Diospyros kaki Thun B.) mengandung flavonoid, tanin, asam organik, dan fenol (Isnindar et al., 2011). Tumbuhan daun Diospyros bateri Gurke dilaporkan mengandung alkaloid, saponin dan tanin (Oluremi, 2010). Sedangkan tumbuhan Diospyros anisandra pada kulit kayunya dilaporkan adanya plumbagin (Borges et al., 2007). Namun demikian, belum banyak artikel ilmiah yang melaporkan aktivitas biologis maupun kandungan kimia yang terkait dengan kayu eboni.

Proses ekstraksi bahan alam dipengaruhi oleh sifat pelarut yang akan digunakan. Suatu senyawa akan mudah larut dalam pelarut yang mempunyai polaritas yang sama atau mirip (Sudarmadji et al., 1989). Menurut prinsip like dissolves like, suatu pelarut akan cenderung melarutkan senyawa yang mempunyai tingkat kepolaran yang sama. Pelarut yang bersifat polar mampu mengekstraksi senyawa komponen fenolik, tannin, asam amino dan glikosida. Pelarut semi polar mampu mengekstrak senyawa fenol, terpenoid, alkaloid dan glikosida. Pelarut non polar dapat mengekstrak senyawa kimia lipid, karotenoid, dan minyak yang mudah menguap (Harborne, 1987). 


\section{METODE PENELITIAN}

\section{Bahan dan Peralatan}

Bahan dasar yang digunakan dalam penelitian ini mencakup kulit batang kayu eboni diambil di daerah Sausu Kab. Parigi. Bahan lainnya berupa bakteri patogen Staphilococcus aureus dan Echericia coli, nutrien agar (NA), aquades, $n$-heksan, etil asetat, etanol, pereaksi dragendrof, kertas saring, serbuk magnesium, $\mathrm{HCl}$ pekat, $\mathrm{H}_{2} \mathrm{SO}_{4}$ pekat dan $\mathrm{FeCl}_{3} 5 \%$, kertas saring, tissue, aluminium foil, klofamfenikol, dan asam asetat anhidrat..

Peralatan yang digunakan dalam penelitian ini adalah neraca analitik, blender, ayakan 60 mesh, oven, , autoklaf (Hirayama), incubator (POL-EKO Aparatura), Laminar Air Flow (Esco Class II BSC), rotary vakum evaporator, jangka sorong, botol semprot, spatula, sendok zat, bunsen, pipet tetes, dan jarum ose.

\section{Prosedur Penelitian}

\section{Ekstraksi Kulit Batang Kayu Eboni (Nurbaya, 2015)}

Serbuk kulit batang kayu eboni sebanyak $100 \mathrm{gr}$ ekstraksi menggunakan metode maserasi dengan tiga jenis pelarut yaitu $n$-heksan, etil asetat dan etanol. Masing - masing ekstrak $n$-heksan, etil asetat dan etanol dilakukan uji fitokimia dan uji antibakteri terhadap Staphilococcus aureus dan Echericia coli.

\section{Uji Fitokimia (Harborne, 1987)}

\section{Uji Alkaloid}

Uji alkaloid dilakukan dengan cara memasukkan $1 \mathrm{ml}$ ekstrak ke dalam tabung reaksi lalu ditambahkan 2-3 tetes pereaksi dragendorf. Hasil positif adanya alkaloid ditunjukkan dengan terbentuknya endapan oranye/jingga.

\section{Uji Flavonoid}

Sebanyak $1 \mathrm{ml}$ ekstrak ditambahkan 0,5 gram serbuk magnesium dan 10 tetes $\mathrm{HCl}$ pekat, bila bereaksi positif akan menghasilkan larutan berwarna jingga, merah muda atau merah.

\section{Uji Steroid}

Sebanyak $2 \mathrm{ml}$ ekstrak ditambahkan asam asetat anhidrat sebanyak 10 tetes dan asam sulfat pekat sebanyak 2 tetes. Larutan dikocok perlahan dan dibiarkan selama beberapa menit. Adanya steroid ditunjukan oleh warna biru atau hijau, sedangkan triterpenoid memberikan warna merah atau ungu.

\section{Uji Tanin}

Untuk uji tanin, sebanyak $1 \mathrm{ml}$ ekstrak ditambahkan 3 tetes larutan $\mathrm{FeCl} 3$ $5 \%$, bila bereaksi positif akan menghasilkan warna hijau, merah, ungu, biru atau hitam.

\section{Uji Antibakteri}

\section{Persiapan Bahan Uji Antibakteri}

Sebanyak 28 gram nutrient agar (NA) dilarutkan dalam $1000 \mathrm{ml}$ aquades, kemudian di sterilkan kedalam autoclave pada suhu $121^{\circ} \mathrm{C}$ dengan tekanan $1 \mathrm{~atm}$ selama 15 menit.

\section{Pengujian Aktivitas Antibakteri Dengan Metode Sumur Difusi (Darmawati, 2009)}

Pada pengujian zona hambat bakteri digunakan metode sumur difusi. Media 
nutrien agar (NA) sebanyak $25 \mathrm{ml}$ dicampur dengan $25 \mu \mathrm{L}$ suspensi bakteri uji (Staphilococcus aureus dan Eschericia coli), dihomogenkan lalu dituang dalam cawan petri steril dan dibiarkan sampai memadat. Setelah itu dibuat sumur yang berdiameter $\pm 6 \mathrm{~mm}$ dengan menggunakan alat pelubang. Setiap cawan berisi 3 lubang atau sumur (lubang pertama untuk control negatif berupa pelarut $n$-heksan, lubang kedua untuk kontrol positif berupa Kloramfenikol $0,1 \%$ dan 1 lubang untuk ekstrak $n$-heksan), setiap sumur diisi ekstrak dengan kontrol sebanyak $30 \mu \mathrm{L}$, untuk ekstrak etil asetat dan etanol dilakukan perlakuan yang sama kemudian diinkubasi selama 24 jam pada suhu $37^{\circ} \mathrm{C}$, selanjutnya diamati dan diukur diameter zona hambat dengan jangka sorong.

\section{HASIL DAN PEMBAHASAN}

\section{Metabolit Sekunder dalam Ekstrak Kulit Kayu Eboni}

Pada kulit kayu eboni mengandung senyawa metabolit sekunder yang dapat berperan sebagai atibakteri. Untuk menganalisis senyawa metabolit sekunder yang terdapat pada kulit kayui eboni perlu dilakukan skrining fitokimia. Skrining fitokimia merupakan suatu proses untuk mengidentifikasi kandungan kimia pada suatu tumbuhan, diantaranya alkaloid, saponin, tannin dan senyawa fenolik.

Ekstrak $n$-heksana kulit ayu eboni terdeteksi adanya senyawa steroid, tetapi tidak terdeteksi adanya alkaloid, flavonoid dan tannin (Tabel 1). Hal tersebut memberikan keterangan dalam kulit kayu eboni terdapat senyawa steroid yang bersifat non polar. Untuk ekstrak etil asetat terdeteksi adanya tanin dan alkaloid. Kedua senyawa ini juga terdeteksi dalam ekstrak etanol, yang berarti tanin dan alkaloid yang ada pada kulit kayu eboni terdiri atas tanin dan alkaloid semi polar serta tanin dan alkaloid polar. Menurut Lestiani dan Lanny (2008), tingkat kepolaran pelarut menentukan jenis senyawa yang dapat diekstrak dari sampel. Pelarut akan mengekstrak senyawa-senyawa yang mempunyai kepolaran yang sama atau mirip dengan kepolaran pelarut yang digunakan.

Tabel 1 Hasil analisis golongan senyawa ekstrak kulit kayu eboni dari ketiga jenis pelarut.

\begin{tabular}{cccc}
\hline \multirow{2}{*}{$\begin{array}{c}\text { Golongan } \\
\text { senyawa }\end{array}$} & $\begin{array}{c}\boldsymbol{n} \text { Jenis Ekstrak } \\
\text { heksan }\end{array}$ & $\begin{array}{c}\text { Etil } \\
\text { asetat }\end{array}$ & Etanol \\
\hline Flavonoid & - & - & + \\
Alkaloid & - & + & + \\
Steroid & + & - & - \\
Tannin & - & + & + \\
\hline Keterangan: & & &
\end{tabular}

Keterangan:

(+) : Terdeteksi adanya senyawa

(-) : Tidak terdeteksi adanya senyawa

Golongan senyawa flavonoid terdeteksi dalam ekstrak etanol, tetapi tidak terdeteksi dalam ekstrak etil asetat maupun ekstrak n-heksan (Tabel 1), yang menunjukkan flavonoid yang ada dalam kulit kayu eboni adalah flavonoid yang bersifat polar.

\section{Aktifitas Antibakteri dan Daya Hambat Ekstrak Kulit Kayu Eboni}

Berdasarkan hasil uji antibakteri terhadap Staphylococcus aureus dan 
Eschericia coli masing-masing 3 kali pengulangan diperoleh perbedaan zona hambat dari masing-masing ekstrak nheksan, etil asetat dan etanol. Uji aktivitas ekstrak kulit kayu eboni terhadap pertumbuhan bakteri gram positif (Staphylococcus aureus) dan gram negatif (Eschrichia coli) dengan menggunakan metode sumur difusi, yang di tandai dengan terbentuknya zona bening di sekitar sumuran. Antibiotik Chloramphenicol sebagai kontrol positif dan kontrol negatif berupa 3 pelarut yaitu n-heksan, etil asetat dan etanol. Pengamatan terhadap diameter zona hambat dari masing-masing ekstrak dengan pengukuran menggunakan jangka sorong digital.

Tabel 2 Hasil zona hambat bakteri gram negative Esherichia coli dan bakteri gram positif Staphylococcus aureus.

\begin{tabular}{ccc}
\hline \multirow{2}{*}{ Ekstrak } & \multicolumn{2}{c}{$\begin{array}{c}\text { Diameter Rata-rata Zona } \\
\text { Hambat (mm) }\end{array}$} \\
\cline { 2 - 3 } & $\begin{array}{c}\text { Eschericia } \\
\text { coli }\end{array}$ & $\begin{array}{c}\text { Staphylococcus } \\
\text { aureus }\end{array}$ \\
\hline $\begin{array}{c}n \text {-heksan } \\
\text { Etil } \\
\text { asetat }\end{array}$ & 0 & 0 \\
Etanol & 26,14 & 23,38 \\
\hline \multicolumn{2}{c}{ Kontrol positif chloramphenicol } \\
\hline$n$-heksan & 28,52 & 28,66 \\
Etil & 28,19 & 29,47 \\
Asetat & 28,23 & 29,12 \\
Etanol & \multicolumn{3}{c}{ Kontrol negatif pelarut } \\
\hline $\begin{array}{c}n- \\
\text { Heksan }\end{array}$ & 0 & 0 \\
Etil & 0 & 0 \\
asetat & 0 & 0 \\
Etanol & 0 & 0 \\
\hline
\end{tabular}

Ekstrak n-heksan tidak memberikan daya hambat terhadap semua bakteri uji. Ekstrak etil asetat yang mengandung alkaloid dan tannin memberikan zona hambat terhadap semua bakteri uji, meskipun diameter zona hambatnya berbeda-beda (Tabel 2). Hal ini sesuai dengan Parekh et al., (2005) juga menemukan bahwa, aktivitas antibakteri dipengaruhi oleh polaritas senyawa yang diekstraksi oleh masing-masing pelarut dengan kemampuan zat tersebut untuk menyebar pada media yang digunakan dalam pengujian aktivitas antibakteri. Tanin pada tanaman digunakan sebagai proteksi dari mikroorganisme yang mensekresikan enzim yang dapat membuat dinding sel tanaman lisis, enzim ini akan inaktif ketika tanin yang ada pada tanaman terikat dengan enzim yang disekresikan oleh mikroorganisme patogen tersebut (Heldt dan Hans, 2004).

Ekstrak etanol mengandung senyawa-senyawa polar (flavonoid, alkaloid dan tanin) juga memberikan zona hambat terhadap semua bakteri uji. Zona hambat tertinggi $(25,97 \mathrm{~mm})$ ditemukan pada Staphylococcus aureus dan zona hambat terendah $(23,78)$ ditemukan pada Esherichia coli. Kandungan ekstrak etanol berupa senyawa flavonoid merupakan kelompok senyawa fenol yang berperan dalam mengikat protein, sehingga menganggu proses metabolisme (Ganiswara, 1995). Sabir (2005) dalam penelitiannya menjelaskan bahwa gugus hidroksil yang terdapat pada struktur senyawa flavonoid akan mengakibatkan timbulnya efek toksik terhadap bakteri. Sedangkan untuk ekstrak tanin terdiri dari 
campuran senyawa polifenol yang sangat kompleks dan biasanya tergabung dari karbohidrat rendah seperti glukosa (Linggawati et al., 2002). Senyawa tanin dapat berperan sebagai antibakteri karena dapat menganggu sintesa peptidoglikan sehingga pembentukan dinding sel bakteri menjadi kurang sempurna. Etanol absolut memiliki efek bakterisidal yang lebih lemah dibandingkan campuran antara alkohol dan air. $100 \%$ etanol mengkoagulasi protein pada dinding sel, sehingga terjadi pengerasan protein pada dinding sel.

Menurut Parekh et al., (2005) aktivitas antibakteri dipengaruhi oleh polaritas senyawa yang diekstraksi oleh masing-masing pelarut. Menurut Schlegel (1993), bahwa setiap senyawa dapat memberikan efek yang berbeda dalam menghambat pertumbuhan bakteri. Perbedaan aktivitas yang terjadi disebabkan oleh metabolit sekunder yang terkandung memiliki efek sinergis yang berbeda tergantung dari sifat dan morfologi dari bakteri tersebut. Faktor lain yang menyebabkan perbedaan diameter zona hambat dari ekstrak tersebut adalah perbedaan senyawa aktif yang terdapat pada ekstak. Hal ini sesuai dengan pendapat Prescott (2005), bahwa ukuran dari zona hambat dipengaruhi oleh beberapa hal, seperti tingkat sensitifitas dari organisme uji, kecepatan difusi dari senyawa antibakteri dan konsentrasi senyawa antibakteri.
Menurut Davis dan Stout (1971) dalam Arista (2013), berdasarkan zona jernih atau zona bening yang terbentuk, daya hambat dikelompokkan menjadi 4 kelompok yaitu sangat kuat bila zona hambat $>20 \mathrm{~mm}$, kuat $10-20 \mathrm{~mm}$, sedang 5-10 $\mathrm{mm}$ dan lemah $<5 \mathrm{~mm}$. Berdasarkan pernyataan Davis dan Stout (1971) Senyawa antibakteri dalam ekstrak etil asetat dan etanol dapat dikategorikan antibakteri daya hambat sangat kuat terhadap kedua bakteri uji.

\section{KESIMPULAN}

Ekstrak kulit batang kayu eboni mempunyai aktivitas antibakteri terhadap bakteri Staphylococcus aureus dan Esherichia coli. Ekstrak etil asetat kulit kayu eboni memilki aktivitas antibakteri yang sangat kuat terhadap bakteri gram positif Esherichia coli dengan zona hambat 26,14 $\mathrm{mm}$, sedangkan ekstrak etanol kulit kayu eboni memiliki aktivitas sangat kuat terhadap bakteri gram negatif Staphylococcus aureus dengan zona hambat $25,97 \mathrm{~mm}$.

\section{DAFTAR PUSTAKA}

Allo K.M. 2011. Pengenalan Waktu Berbuah Eboni (Diospyros celebica Bakh.) Pada Beberapa Tempat Tumbuh Di Sulawesi. Makassar: Balai Penelitian Kehutanan Makassar.

Arista, Y. N. 2013. Formulasi dan Uji Aktivitas Gel Antijerawat Ekstrak Umbi Bakung (Crinum Asiaticum L.) terhadap Bakteri Staphylococcus aureus secara In Vitro. (http://ejournal.unstrat.ac. id/index. 
php/pharmacon/article/ view/1552). Diakses 1 April 2019.

Borges. AR, Isabel. C, Luiz. M, Said. SF, dan Maria, G. 2007. Antimicrobial activity of Diospyros anisandra. Fitoterapia, $78:$ 370-372.

Darmawati, S. 2009. Keanekaragaman Genetik Salmonella typhi. Jurnal Kesehatan, 2 (1): 28-32.

Dzen, Sjoekoer M., et al. 2003. Bakteriologi Medik. Edisi 1. Malang: Bayumedia Publishing.

Ganiswara, S.G. 1995. Farmakologi dan terapi Edisi ke-4. Jakarta: FRUT.

Harborne, J. B., 1987, Metode Fitokimia Penuntun Cara Modern Menganalisis Tumbuhan, Edisi kedua, Hal 5, 69-76, diterjemahkan oleh Kosasih Padmawinata dan Iwang Soedira. Bandung: ITB Press.

Heldt dan Hans. 2004. Plani Biochemistry. New York: Elsevier Academic Press.

Isnindar, Wahyuono. S, Setyowati.E.P. 2011. Aktivitas Antioksidan Daun Kesemek (Diospyros kaki L.F) Dengan Metode DPPH (2,2-Difenil-1 Pikrilhidrazin). Majalah Obat Tradisional, 16(2): $63-67$.

Linggawati, A., Muhadariana, Erman, Azman dan Midiarty. 2002. Pemanfaatan tanin limbah kayu industri kayu lais untuk modifikasi resin fenol formaldehid. Jurnal Natur Indonesia, 4 (1) 165-171.

Mallavadhani. U. V. 1998. Pharmacology and Chemotaxonomy of Diospyros. India: Regional Research Laboratory (CSIR), Bhubaneswar-751 013, Orissa,

Nurbaya. 2015. Kajian Ekstrak Etanol Bunga Kembang Telang (Clitoria ternate) Sebagai Bioindikator
Asam Basa. Skripsi. Palu: MIPA Universitas Tadulako.

Oluremi, B. B., Osungunna, M O., Ogbole, O O. 2010. Phytochemical and Antimicrobial Screening of the Leaf Extract of Diospyros barteri Gurke. Pharmacognosy Journal, 2(11):405-408.

Parekh, J., Jadeja, D., Candra, S. 2005. Efficaccy of Aqueous and Mathanol Extracts of Some Medicinal Plants for Potential Antibacterial Activity. Turk J Biol ., 29:203-210.

Prescott, LM. 2005. Microbiology. New York: Mc.Grow-Hill.

Sabir, A. 2005. Aktivitas Antibakteri flavonoid Propolis trigono sp terhada bakteri Streptococcus mutans (in Vitro). Majalah Kedokteran Gigi, 38(3): 135-141.

Schlegel, G. Hans. 1993. General Microbiologi. Seventh Edition. England: Cambridge University Press.

Sudarmadji, S., Haryono, B., \& Suhardi. 2007. Analisa Bahan Makanan dan Pertanian. Yogyakarta:Liberty. hal 93-94. Biology, vol. 864. New York: Springer Science : 